\title{
A Soluble Acidic Protein of the Cell Nucleus which Reacts with Serum from Patients with Systemic Lupus Erythematosus and Sjögren's Syndrome
}

\author{
Masashi Akizuki, Runas Powers, Jr., and Halsted R. Holman \\ From the Division of Immunology, Department of Medicine, Stanford University School of Medicine, \\ Stanford, California 94305
}

\begin{abstract}
A B S T RACT A soluble nuclear antigen that reacts with sera obtained from patients with systemic lupus erythematosus and Sjögren's syndrome has been described. The antigen, tentatively named the $\mathrm{Ha}$ antigen after the prototype serum, was shown to react with specific antibodies by precipitin, complement fixation, and immunofluorescence techniques. The $\mathrm{Ha}$ antigen prepared from isolated nuclei of calf thymus glands, calf liver, and rat liver showed identical immunological reactivities; a wide distribution among different species and tissues is presumed. The Ha antigen was destroyed by trypsin and relatively mild heat or $\mathrm{pH}$ variation from neutrality, but was resistant to DNase or RNase. Many of these characteristics are similar to those of the " $B$ " antigen to which antibodies have recently been described in Sjögren's syndrome. The nuclear origin of the $\mathrm{Ha}$ antigen was confirmed by the speckled nuclear immunofluorescence staining pattern given by purified antibody to $\mathrm{Ha}$ obtained from a specific immune precipitate. Preliminary results showed approximately $13 \%$ of patients with systemic lupus erythematosus and $30 \%$ of patients with Sjögren's syndrome had precipitating antibodies to the $\mathrm{Ha}$ antigen.
\end{abstract}

\section{INTRODUCTION}

Antinuclear antibodies are common in serums of patients with systemic lupus erythematosus. Specifici-

Dr. Akizuki is a Research Associate, Department of Medicine. His present address is Arthritis Rheumatism Branch, National Institute of Arthritis, Metabolic, and Digestive Diseases, Bethesda, Md. 20014. Dr. Powers is a Research Associate and Dr. Holman is a Professor of Medicine at the Department of Medicine, Stanford University School of Medicine.

Received for publication 2 July 1976 and in revised form 1 October 1976. ties of antinuclear antibodies have been shown to be directed toward a variety of antigens such as DNA (1-4), deoxyribonucleohistone (5), histone $(6,7)$, RNA $(8,9)$, nucleolar antigens $(10-12)$, and constituents of the soluble nuclear extract (13-17). The soluble nuclear extract contains several macromolecules with different antigenic specificities. Antibodies to at least two of them, the nuclear ribonucleoprotein antigen $(\mathrm{RNP})^{1}$ described by Mattioli and Reichlin, and the Sm antigen described by Tan and Kunkel have clinical implications (15-20). ${ }^{2}$

This report concerns another antigen found in the soluble nuclear extract from calf thymus glands, calf liver, and rat liver. Sera which react specifically with this antigen, designated the $\mathrm{Ha}$ antigen after the original serum, were obtained from patients with systemic lupus erythematosus (SLE) and Sjögren's syndrome. The characteristics of the antigen will be compared with those of the Sm and RNP antigens.

Recently Alspaugh and Tan and Alspaugh et al. reported three precipitating systems between serums from patients with Sjögren's syndrome and an extract from cultured human lymphocytes. $(21,22)$. Properties of their " $B$ " antigen were similar to, but not identical with, those of the $\mathrm{Ha}$ antigen. Comparative immunodiffusion of the " $B$ " antigen and its antiserums with the $\mathrm{Ha}$ antigen and its antiserums shows lines of identity.

We have retained the informal practice of labeling an unknown cellular antigen by the first two letters of the name of the patient whose serum was used

\footnotetext{
${ }^{1}$ Abbreviations used in this paper: MCTD, mixed connective tissue disease; RNP, ribonucleoprotein antigen.

${ }^{2}$ Powers, R., M. Akizuki, M. J. Boehm-Truitt, V. Daly, and H.Holman. 1976. Substantial purification of the SM Antigen and association of high titer antibody to $\mathrm{SM}$ with a clinical subset of SLE. Abstract presented to American Rheumatism Association Scientific Meeting, December 1976.
} 
in identifying the antigen (eg., Sm, Ro, Ha). While undesirable, this system is well established in the literature. As these antigens are better characterized, more accurate names will be substituted (e.g., nuclear ribonucleoprotein or RNP).

\section{METHODS}

Reference sera. Reference sera were selected from the serum bank of the Clinical Immunology Laboratory, Stanford University Medical Center. The serum HA showed a precipitin reaction in agar against the nuclear extract which was distinct from the Sm or RNP precipitins. It gave a high titer $(1: 1280)$ speckled fluorescent antinuclear antibody reaction, was negative for the Sm and RNP antibodies by hemaggluti. nation, and had a rheumataid factor titer of 1:2560. Two other sera, HU from a patient with SLE and DA from a patient with mixed connective tissue disease (MCTD), were utilized to identify the Sm and RNP antigens, respectively. These sera were identical in immunological specificities to standard sera used by Drs. E. M. Tan and M. Reichlin.

Patients. Serums were obtained from 271 patients with various connective tissue diseases. 137 patients with SLE showed the characteristic multisystem disease and immunological abnormalities (23). 47 patients with scleroderma had typical skin changes with at least two organ systems involved. 45 patients with classical or definite rheumatoid arthritis were chosen according to the criteria of the American Rheumatism Association (24). 11 patients with polymyositis met the criteria described by Medsger et al. (25). 16 patients with MCTD were described in previous papers $(16,18)$. Sera from 15 patients with Sjögren's syndrome were kindly supplied by Dr. N. Talal. The 20 normal controls were healthy laboratory personnel.

\section{Nuclear extract}

Isolation of nuclei. Preparation of calf thymocyte nuclei has been described elsewhere (26). The nuclei of calf liver and rat liver were isolated by the method described by Maggio et al. with some modifications (27). Briefly, the fresh liver was irrigated with cold saline via portal veins, cleansed of visible vessels and connective tissue, cut into small pieces, and gently homogenized in $0.88 \mathrm{M}$ sucrose solution with $1.5 \mathrm{mM} \mathrm{CaCl} \mathrm{C}_{2}$ with a Teflon homogenizer. The sucrose concentration of the homogenate was raised to approximately $1.6 \mathrm{M}$ by adding $1.2 \mathrm{vol}$ of $2.2 \mathrm{M}$ sucrose with $1.5 \mathrm{mM} \mathrm{CaCl}$. After filtering through four layers of gauze, $25 \mathrm{ml}$ of homogenate was layered over $10 \mathrm{ml}$ of $2.2 \mathrm{M}$ sucrose solution containing $0.5 \mathrm{mM} \mathrm{CaCl}_{2}$ and centrifuged for $90 \mathrm{~min}$ at $76,000 \mathrm{~g}$. The pellets of nuclei were washed twice with $0.25 \mathrm{M}$ sucrose with $0.5 \mathrm{mM} \mathrm{CaCl}_{2}$ and used for an extraction of antigens. The nuclei showed less than $1 \%$ contamination with intact cells by crystal violet staining.

Preparation of the soluble nuclear extract. Washed nuclei were resuspended in cold $0.15 \mathrm{M} \mathrm{NaCl}$ solution (one part of nuclear pellet to nine parts of saline), disrupted by a Virtis homogenizer (Virtis Company, Gardiner, N. Y.) at maximum speed for $45 \mathrm{~s}$, and allowed to stand at $4^{\circ} \mathrm{C}$ overnight. The suspension was centrifuged at $106,000 \mathrm{~g}$ for $120 \mathrm{~min}$. The antigen preparation that has been used to detect the anti-Sm and anti-RNP antibodies by hemagglutination in our laboratory is prepared by precipitation of the supernate with ethanol at $86 \%$ saturation at room temperature (14). Because this procedure damages the $\mathrm{Ha}$ antigen, the super- nate was dialysed against isotonic saline, and stored at $-20^{\circ} \mathrm{C}$. This final material was designated as the nuclear extract and used throughout this study. All procedures to prepare the nuclear extract were carried out at $4^{\circ} \mathrm{C}$. Because the soluble nuclear antigens in this study showed the same immunological and physiochemical characteristics regardless of source of nuclei, results obtained with the calf thymus nuclear extract will be presented in this paper unless otherwise indicated.

\section{Immunological techniques}

Immunodiffussion. The Ouchterlony double diffusion method was used to demonstrate and identify the precipitin reactions between the nuclear extract and specific antibodies. $25 \mathrm{ml}$ of $0.6 \%$ agarose in phosphate buffered saline $\mathrm{pH} 7.2$, $0.01 \mathrm{M}$ phosphate containing $0.1 \%$ sodium azide and $0.01 \%$ trypan blue) were pipetted into a Petri dish $(100 \times 15 \mathrm{~mm})$ (28). Wells of $7 \mathrm{~mm}$ in diameter were placed $4 \mathrm{~mm}$ apart.

Complement fixation test. A quantitative complement fixation microtest was performed by the method of Wasserman and Levine in a total reaction vol of $0.7 \mathrm{ml}(29)$. A veronal buffered saline with $\mathrm{Mg}$ and $\mathrm{Ca}$ containing bovine serum albumin at a concentration of $0.1 \%$ was used (30).

Passive hemagglutination. The method of hemagglutination described by Sharp et al. and Stavitsky was used, modified as reported elsewhere $(16,31)$.

Immunofluorescent test. The standard indirect fluorescent antibody technique was employed with cryostat-cut rat or mouse liver sections and antiserum to human IgG conjugated with fluorescein isothiocyanate (32).

Gel filtration. The nuclear extract was fractionated on Sephadex columns of various porosities.

Ion exchange chromatography. The active antigen preparations were chromatographed on DEAE cellulose as well as DEAE Sephadex A-50 according to the method of Clark et al. (33). Ion exchangers were equilibrated with an initial buffer (0.05 M Tris- $\mathrm{HCl}, \mathrm{pH} 7.2)$ and the nuclear extract was eluted with a linear salt gradient with $0.05 \mathrm{M}$ Tris- $\mathrm{HC} 1,0.40 \mathrm{M}$ $\mathrm{NaCl}, \mathrm{pH} 7.2$ as a limiting buffer.

Zone centrifugation. Sucrose density gradient centrifugation of patients' serum and the nuclear extract was carried out according to the method of Kunkel (34). A sample of $0.2 \mathrm{ml}$ was layered over $5 \mathrm{ml}$ of sucrose gradient from 10 to $30 \%$, centrifuged at $100,000 \mathrm{~g}$ for $18 \mathrm{~h}$ in $\mathrm{SW}-50$ rotor and fractions were collected from the bottom.

Immunoelectrophoresis. The patients' sera and the nuclear extract were studied by a standard immunoelectrophoresis

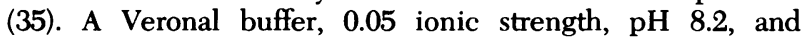
$1.2 \%$ agarose were used.

Specific antibody to the $\mathrm{Ha}$ antigen. To determine the intracellular location of the $\mathrm{Ha}$ antigen, the specific antibody was prepared with immune precipitates (17). Precipitates from the early equivalence zone were washed three times with cold saline and dissolved in $0.02 \mathrm{M}$ citrate buffer, $\mathrm{pH}$ 3.2. The suspension was heated at $56^{\circ} \mathrm{C}$ for $45 \mathrm{~min}$ and then dialyzed against cold saline. Immunoglobulins were recovered by gel filtration on Sephadex G-100 or ammonium sulfate precipitation at $40 \%$ saturation.

Removal of rheumatoid factor. The latex particles coated with human gammaglobulins (latex globulin reagent, Div., Hyland Travenol Laboratories, Inc., Costa Mesa, Calif.) were convenient for this purpose. The latex reagent was concentrated by a pressure dialysis and mixed with a test serum. After incubation at $37^{\circ} \mathrm{C}$ for $30 \mathrm{~min}$, the latex particles were removed by centrifugation at $10,000 \mathrm{~g}$ for $30 \mathrm{~min}$ and the supernate was tested for rheumatoid factor activity by latex fixation test. 


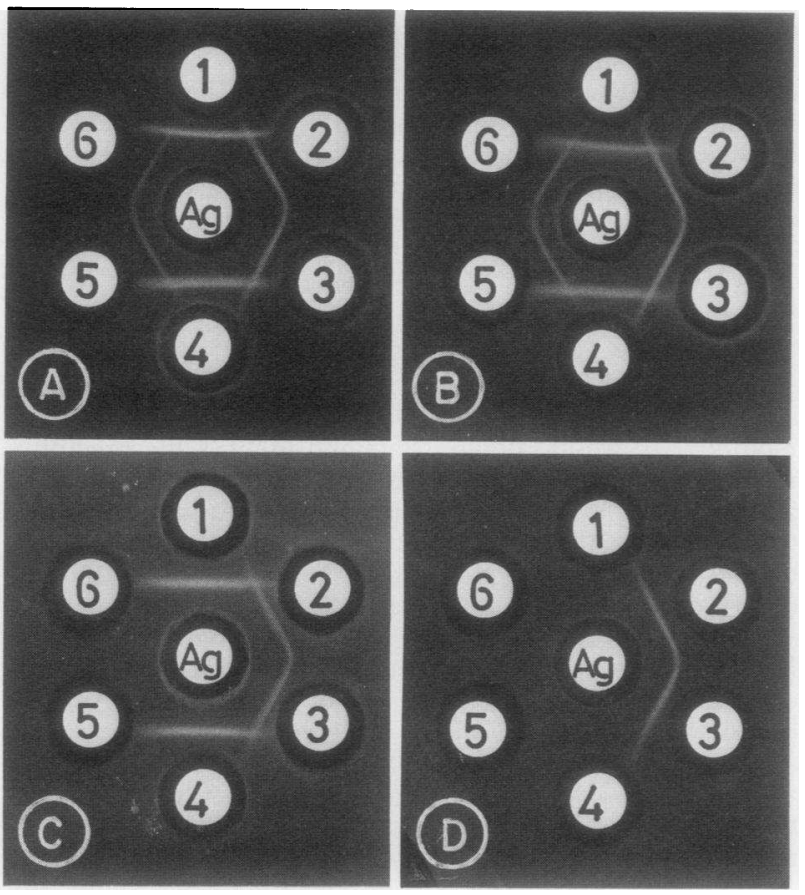

Figure 1 Double diffusion demonstration of the independence of the Ha system from the Sm and the RNP systems. Serum HA (ā-Ha) was placed in wells 1,4 . Serum $\mathrm{HU}$ $(\bar{a}-\mathrm{Sm})$ in wells 2,3 , and serum DA (ā-RNP) in wells 5,6 . The central well contained the calf thymus nuclear extract (50 $\mathrm{mg} / \mathrm{ml}$ ). The apparent spurrings of the $\mathrm{Ha}$ system through the precipitin lines of the $\mathrm{Sm}$ and the RNP systems are seen (Fig. 1A). The different antigen sensitivities to the enzyme treatments are also illustrated (DNase $20 \mu \mathrm{g} / \mathrm{ml}$, Fig. 1B: RNase $20 \mu \mathrm{g} / \mathrm{ml}$, Fig. IC and trypsin $100 \mu \mathrm{g} / \mathrm{ml}$, Fig. 1D).

Sensitivity to enzyme treatment, heating, and $p H$ variations. Enzymatic digestion of the nuclear extract was performed according to Holman and Deicher (26). Since the activity of the antigen was shown to decline at $37^{\circ} \mathrm{C}$, enzyme treatment was done at $22^{\circ} \mathrm{C}$ for $2 \mathrm{~h}$. Bovine pancreatic trypsin, soy bean trypsin inhibitor, deoxyribonuclease (DNase), and ribonuclease (RNase) were obtained commercially (Worthington Biochemical Corp., Freehold, N. J.). The protein, DNA and RNA concentrations of the nuclear extract were measured chemically $(36-38)$ and various enzyme: substrate ratios were employed. The sensitivity of the $\mathrm{Ha}$ antigen to a wide range of $\mathrm{pH}$ changes, and heating at $37^{\circ}$ or $56^{\circ} \mathrm{C}$ were studied by the method of Mattioli and Reichlin (17).

\section{RESULTS}

Distinctive specificity of the Ha antigen. The immunological specificity of the $\mathrm{Ha}$ antigen was first demonstrated by double diffusion (Fig. 1). The precipitin lines developed by the serum HA (wells 1,4) against the nuclear extract $(\mathrm{Ag})$ showed independence from the $\mathrm{Sm}$ (serum $\mathrm{HU}$, wells 2,3) and the RNP (serum DA, wells 5,6) systems (Fig. 1A). The spurrings of the $\mathrm{Ha}$ lines through the precipitin lines of the
Sm and RNP systems are clearly seen. Differences among the three antigens, were also demonstrated by enzyme treatment of the nuclear extract. The $\mathrm{Ha}$ antigen was resistant to DNase at final concentration $20 \mu \mathrm{g} / \mathrm{ml}$ (Fig. 1B) and RNase at $20 \mu \mathrm{g} / \mathrm{ml}$ (Fig. 1C) but was destroyed by trypsin at $100 \mu \mathrm{g} / \mathrm{ml}$ (Fig. 1D). The RNP antigen was abolished by both RNase and trypsin treatment whereas the Sm antigen was unaffected by either. Various enzyme to substrate ratios (DNase: 100:1, 10:1, 1:1, 1:10, 1:100, RNase: 10:1, 1:1, 1:10, $1: 100$, trypsin: $1: 100,1: 500$ ) gave the same results.

The immunological reactions of the Ha system were next studied by complement fixation (Fig. 2). The results of the quantitative complement fixation microtests obtained by the original nuclear extract (no

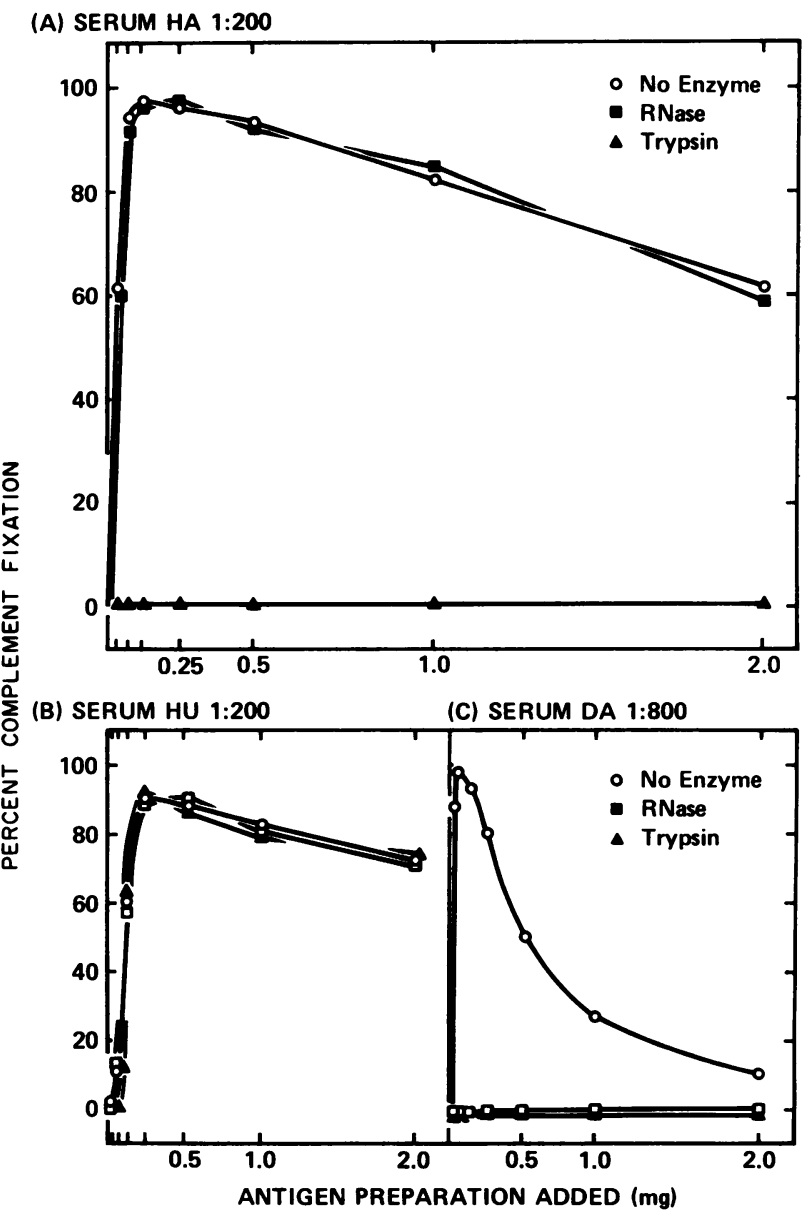

FIGURE 2 Differentiation of the $\mathrm{Ha}$ antigen from the $\mathrm{Sm}$ and RNP antigens by quantitative complement fixation. The reactions between the serum $\mathrm{HA}$ and the calf thymus nuclear extract were abolished by digestion of the nuclear extract with trypsin $(100 \mu \mathrm{g} / \mathrm{ml})$ but not with RNase $(20 \mu \mathrm{g} / \mathrm{ml})$ (Fig. 2A). The Sm system (serum HU, Fig 2B) was not affected by the enzymes and the RNP reaction (serum DA, Fig. 2C) was destroyed by both. None of the antigens were affected by DNase $(20 \mu \mathrm{g} / \mathrm{ml})$. 
TABLE I

Comparison of the Immunological Methods to Detect the Reactions of the Ha, Sm, and RNP Systems

\begin{tabular}{|c|c|c|c|c|c|c|c|c|c|}
\hline \multirow[b]{2}{*}{ Patient } & \multirow{2}{*}{\multicolumn{2}{|c|}{ FANA* }} & \multirow{2}{*}{$\begin{array}{l}\text { Immuno- } \\
\text { diffusion } \ddagger\end{array}$} & \multicolumn{3}{|c|}{ Complement fixation $\S$} & \multicolumn{3}{|c|}{ Haemagglutination" } \\
\hline & & & & Control & RNase & Trypsin & Control & RNase & Trypsinf \\
\hline H. A. & $1: 640 \quad \mathrm{~S}$ & $\mathbf{S}$ & $\overline{\mathrm{a}}-\mathrm{Ha}$ & 98 & 97 & $\mathbf{0}$ & - & - & - \\
\hline C. $\mathrm{O}$. & $1: 1280 \mathrm{~S}$ & $\mathbf{S}$ & $\overline{\mathrm{a}}-\mathrm{Ha}$ & 92 & 95 & 6 & - & - & - \\
\hline H. U. & $1: 640 \quad \mathrm{~S}$ & $\mathbf{S}$ & $\bar{a}-\mathrm{Sm}$ & 88 & 90 & 90 & $1: 10,000$ & $1: 10,000$ & $1: 10,000$ \\
\hline L. $O$. & $1: 640 \quad S$ & $\mathbf{S}$ & $\overline{\mathrm{a}}-\mathrm{Sm}$ & 90 & 84 & 86 & $1: 20,000$ & $1: 20,000$ & $1: 20,000$ \\
\hline D. A. & $1: 1280 \mathrm{~S}$ & $\mathbf{S}$ & ā-RNP & 100 & 0 & 0 & $1: 100,000$ & - & - \\
\hline V. A. & $1: 640 \quad \mathrm{~S}$ & $\mathbf{S}$ & ā-RNP & 98 & 0 & 0 & $1: 100,000$ & - & - \\
\hline
\end{tabular}

* FANA, Fluorescent antinuclear antibody titer; S, speckled pattern.

\$ Specificity of precipitating antibodies identified by gel diffusion.

$\$$ Maximum percent of complement fixation with 1:200 diluted serum.

"Titer of haemagglutination.

ๆ Control: nuclear extract in buffer (no enzyme); RNase: RNase digested nuclear extract; trypsin: trypsin digested nuclear extract.

enzyme) and the nuclear extract digested by enzymes (RNase or trypsin) are shown. The strong complement fixing reaction of the $\mathrm{Ha}$ system was abolished by trypsin but not altered by RNase treatment (Fig. 2A). The Sm system was not affected by enzymatic digestion (serum HU, Fig. 2B) and the RNP reaction was eliminated by both RNase and trypsin treatment (serum DA, Fig. 2C). The treatment by DNase did not change the complement fixation curves of any of the three systems (not shown in the Figure).

Reactivity of antibody to the $\mathrm{Ha}$ antigen was unaffected by absorption of sera with DNA, nucleoprotein, histones, yeast RNA, or polyinosinic-polycytidylic acid.

Table I summarizes the results of fluorescent antibody, complement fixation, and hemagglutination reactions with the nuclear extract by sera specific for $\mathrm{Ha}, \mathrm{Sm}$, and RNP antigens as demonstrated by gel diffusion. All the sera had high fluorescent antinuclear antibody titers with speckled nuclear staining and fixed complement strongly. A minimal degree $(6 \%)$ of complement fixation was observed by serum $\mathrm{CO}$ with the trypsin-treated nuclear extract. Because this serum exhibited only a single precipitin line, the $\mathrm{Ha}$ system, the specificities of the posttrypsin complement fixing reaction could not be identified.

Repeated attempts to detect the $\mathrm{Ha}$ system by hemagglutination were not successful. Nuclear extracts from the calf thymus, liver, and rat liver as well as $\mathrm{Ha}$ antigen preparations enriched by salt fractionation or chromatography were tried without success.

Sensitivity of $\mathrm{Ha}$ antigen to $\mathrm{pH}$ and heat. The Ha antigen, like the Sm and RNP antigens, was stable for several months once the nuclear extract was lyophilized. In solution, the antigen was relatively sensitive to $\mathrm{pH}$ and temperature change. Because the demonstration of residual antigenic activity after these treatments depends upon the initial amounts of antigen, complement fixation and precipitation at optimal antigen concentrations were employed for this study. Fig. 3 shows the sensitivities of the antigen to $\mathrm{pH}$ and heat studied by complement fixation. The gradual loss of activity of the $\mathrm{Ha}$ antigen at pH below 6 and above 10 is seen (Fig. 3A). The RNP antigen was also sensitive to $\mathrm{pH}$ changes (serum DA) but the Sm antigen was stable with only a small reduction of complement fixation at extreme conditions (serum HU). Figs. 3B and 3C show the high susceptibility of the $\mathrm{Ha}$ antigen to heat treatment. Even at $37^{\circ} \mathrm{C}$, steady loss of activity occurred and no reactivity was seen after $4 \mathrm{~h}$. At $56^{\circ} \mathrm{C}$, no reaction was observed after $60 \mathrm{~min}$. Here again, the Sm antigen was not affected whereas the RNP was. By immunodiffusion, the precipitin lines of the $\mathrm{Ha}$ system were not observed at $\mathrm{pH} 3.0$, or after $240 \mathrm{~min}$ at $37^{\circ} \mathrm{C}$, or after $60 \mathrm{~min}$ at $56^{\circ} \mathrm{C}$. The RNP system was abolished by $\mathrm{pH}$ below 5 or above 11 , by $360 \mathrm{~min}$ at $37^{\circ} \mathrm{C}$, and by $60 \mathrm{~min}$ at $56^{\circ} \mathrm{C}$. The precipitin reactions of the $\mathrm{Sm}$ system were not altered by these treatments.

Purification of Ha antigen by salt fractionation and precipitation by alcohol. The bulk of the $\mathrm{Ha}$ antigen was precipitated between 60 and $80 \%$ saturation of ammonium sulfate. A small amount of $\mathrm{Sm}$ but no RNP activity was found in this fraction. This proved a reasonable method to purify the $\mathrm{Ha}$ antigen because only about $20 \%$ of the nuclear extract, measured by dry weight, was precipitated in this range. The $\mathrm{Ha}$ antigen was partially soluble at $50 \%$ and insoluble at 86\% saturation of ethanol. Exposure to alcohol reduced $\mathrm{Ha}$ activity and was avoided in this study.

Purification and characterization of the $\mathrm{Ha}$ antigen 
(A) $\mathrm{pH}$

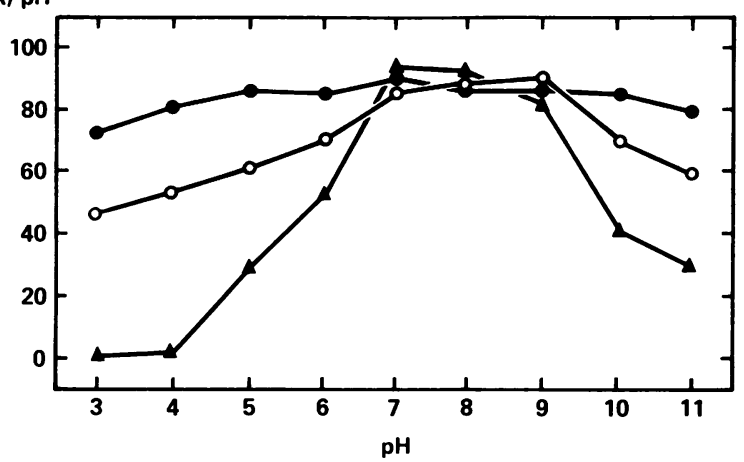

(B) HEAT $\left(37^{\circ} \mathrm{C}\right)$

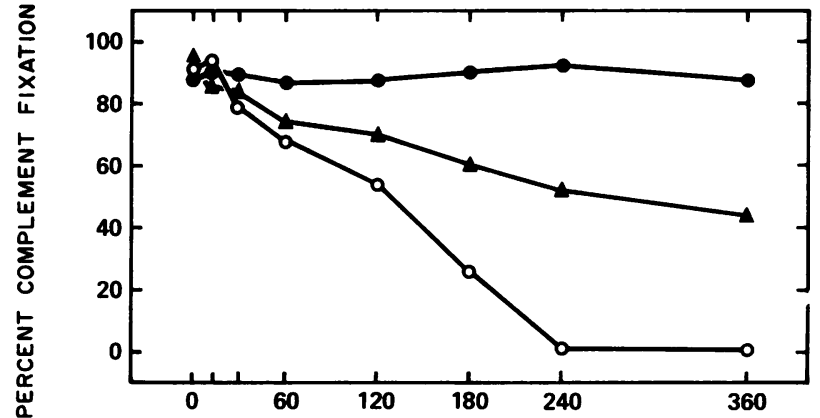

(C) HEAT $\left(56^{\circ} \mathrm{C}\right)$

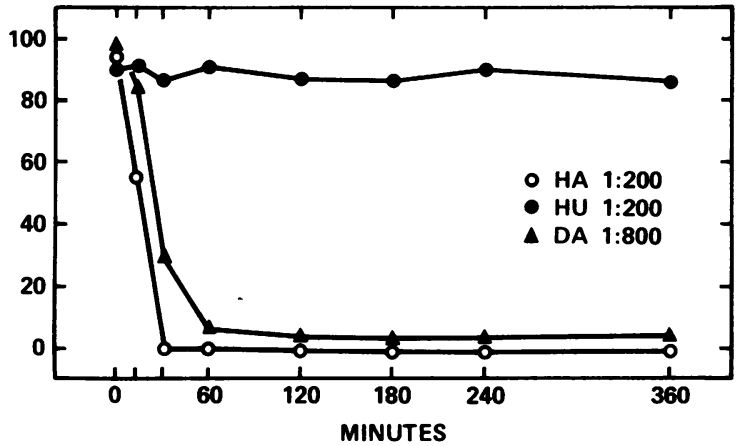

Figure 3 Comparison of the susceptibilities of the Ha, $\mathrm{Sm}$, and RNP antigens to $\mathrm{pH}$ and heat. The calf thymus nuclear extract $(20 \mathrm{mg} / \mathrm{ml})$ was dialyzed overnight in the cold room against buffers of varying $\mathrm{pH}$, neutralized, and the remaining antigenic activities were assessed at antigen concentrations giving maximum complement fixation (Fig 3A). The nuclear extract was exposed to heat $\left(\mathrm{Fig} 3 \mathrm{~B}\right.$, at $37^{\circ} \mathrm{C}$; Fig $3 \mathrm{C}$, at $56^{\circ} \mathrm{C}$ ) for varying periods and the antigenic activities were similarly evaluated.

by gel filtration, ion exchange chromatography, and zone centrifugation. The $\mathrm{Ha}$ antigen was completely excluded by Sephadex G-50, partially excluded by G-75, and included by G-100 columns. Fig. 4 shows the elution curve of the calf thymus nuclear extract with Sephadex G-200. The antigenic activities of fractions examined by complement fixation and gel diffusion are shown. The complement fixation was performed with $50 \mu \mathrm{l}$ of each fraction. The intensity of precipitin reaction was graded by the thickness and position of the lines. The $\mathrm{Ha}$ antigen was eluted between the 7S $\gamma$-globulin and bovine serum albumin markers, and in later fractions than the Sm and RNP antigens. The mol wt of the $\mathrm{Ha}$ antigen was estimated between 50,000 and 150,000 by this method.

Ion exchange chromatography was useful for purification of the nuclear extract (33). A large amount of inactive materials did not bind to the solid phase whereas the antigens $\mathrm{Ha}, \mathrm{Sm}$, and RNP did, and could be eluted by a salt gradient technique. The elution pattern from a DEAE cellulose column is shown in Fig. 5. The $\mathrm{Ha}$ antigen eluted from the column at the concentration of $\mathrm{NaCl}$ between 0.26 and $0.35 \mathrm{M}$. For the DEAE Sephadex column slightly higher concentrations of $\mathrm{NaCl}, 0.28$ to $0.38 \mathrm{M}$ were required. The Sm and RNP activities

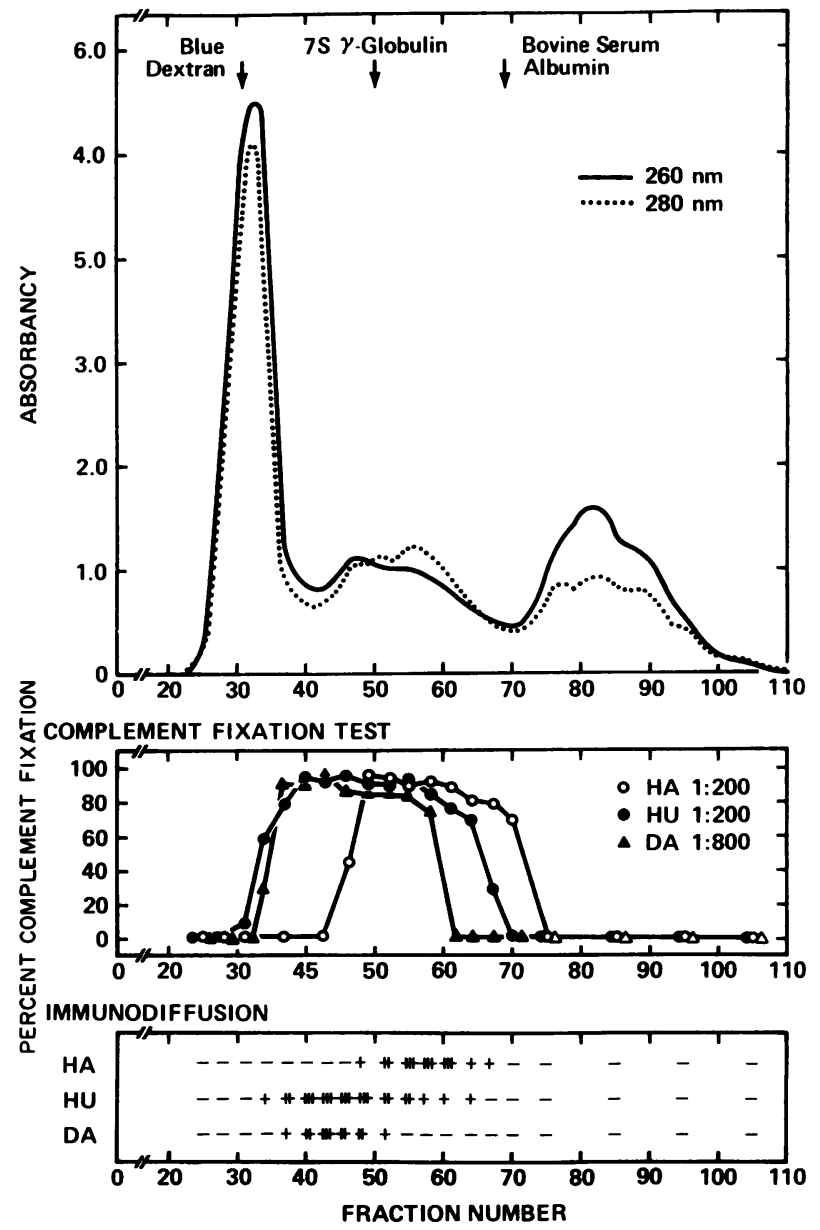

Figure 4 Sephadex G-200 chromatography of the calf thymus nuclear extract. The antigenic activities were studied by complement fixation and confirmed by precipitin reaction. The $\mathrm{Ha}$ antigen was eluted between $7 \mathrm{~S} \gamma$-globulin and bovine serum albumin. The $\mathrm{Sm}$ antigen (detected by serum $\mathrm{HU}$ ) and the RNP antigen (detected by serum DA) were eluted in earlier fractions. 
were eluted at lower salt concentration but there was overlap among the three antigens.

After a sequence of ammonium sulfate fractionation, gel filtration, and ion exchange chromatography, the $\mathrm{Ha}$ antigen was purified approximately 20 times over the original nuclear extract as judged by quantitative complement fixation and agar diffusion techniques. Nevertheless when examined by polyacrylamide gel electrophoresis, the final product showed multiple bands and was therefore still quite impure.

On sucrose density ultracentrifugation, the factor in the serum $\mathrm{HA}$ that reacts with the $\mathrm{Ha}$ antigen was found to sediment in the IgG region (Fig. 6A). The Ha antigen showed slower sedimentation than the Sm and RNP antigens confirming the results obtained by gel filtration (Fig. 6B).

Characterization of the $\mathrm{Ha}$ antigen by immunoelectrophoresis. Electrophoretic mobilities of the serum factor and $\mathrm{Ha}$ antigen were analyzed by standard immunoelectrophoresis (Fig. 7).

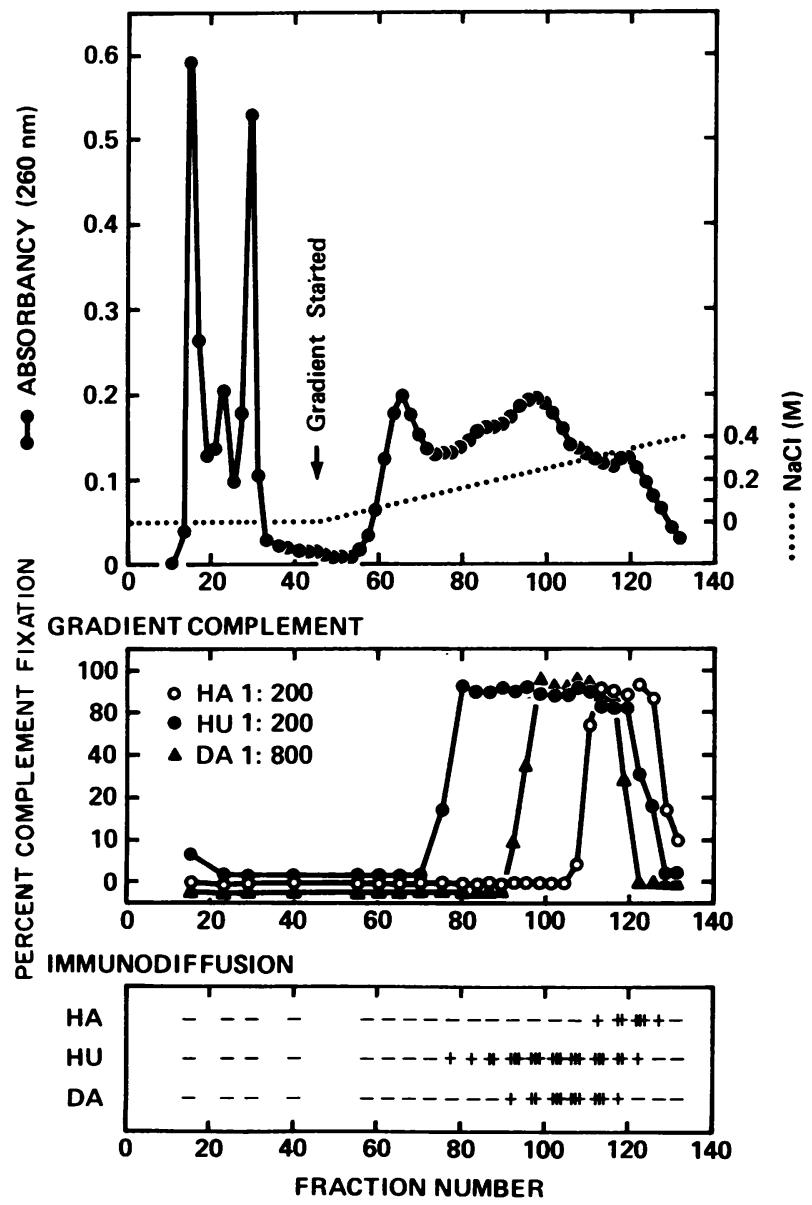

FIGURE 5 Ion exchange chromatography of the calf thymus nuclear extract on DEAE-cellulose. The Ha antigen was eluted at $\mathrm{NaCl}$ concentrations between 0.26 and $0.35 \mathrm{M}$ in later fractions than the Sm and RNP antigens.

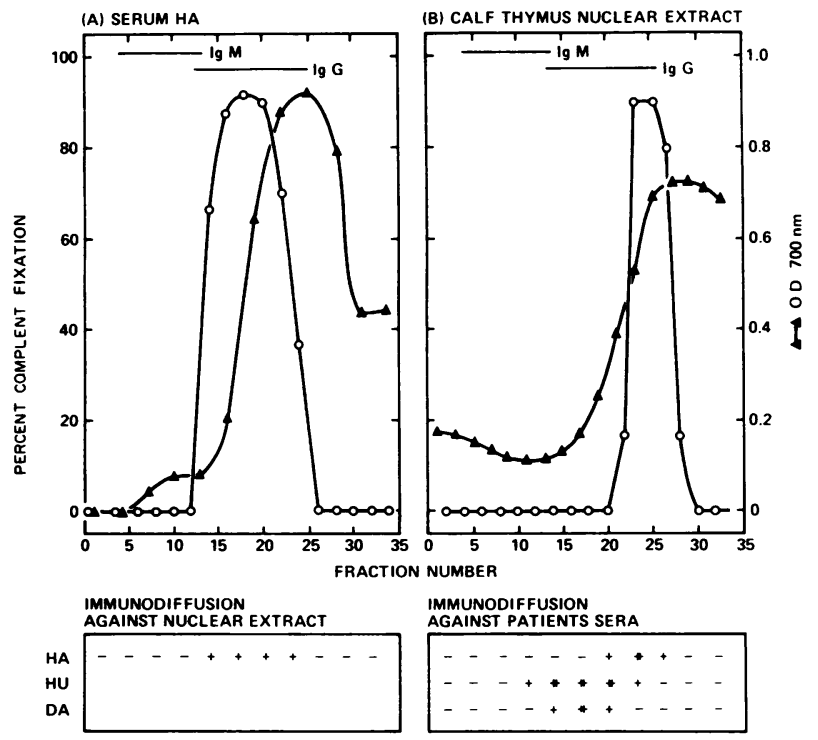

FIGURE 6 Sucrose density gradient ultracentrifugation for fractionation of the serum HA and the calf thymus nuclear extract. $25 \mu \mathrm{l}$ of fractions of the serum $\mathrm{HA}$ and $0.1 \mathrm{mg}$ of the nuclear extract were used for complement fixation (Fig 6A). $50 \mu \mathrm{l}$ of fractions of the nuclear extract were used for complement fixation against the serum HA (1:200) (Fig. 6B).

First, serum HA was electrophoresed for $120 \mathrm{~min}$ and precipitin lines were developed against the calf thymus nuclear extract (upper trough) and antiwhole human serum (ā-WHS) (lower trough) (Fig. 7A). The specific arc was observed exclusively in the $\gamma$-globulin region and considered to be characteristic of IgG by its location and curvature. Five more sera with precipitin antibodies to the $\mathrm{Ha}$ antigen demonstrated the precipitin arcs in the same region.

In Fig. 7B, the electrophoretic mobility of the $\mathrm{Ha}$ antigen was compared with that of normal human serum. The nuclear extract (upper well) and normal human serum (lower well), were electrophoresed for $90 \mathrm{~min}$. In the upper trough, the serum HA was placed and the lower trough was filled with antiwhole human serum (a-WHS). The middle trough was cut and left empty to prevent the reactions between the upper and lower troughs. An anodal mobility of antigen HA was seen in the $\alpha$-globulin region. The Sm and RNP antigens showed a slower anodal mobility (not shown in the Figure).

Intracellular location of the $\mathrm{Ha}$ antigen. Purified antibody prepared from the immune precipitates showed a single precipitin line against the nuclear extract and the characteristic features of the $\mathrm{Ha}$ system by gel diffusion or complement fixation. When the purified antibody was placed on cryostat sections of rat or mouse liver, kidney or thyroid gland, and examined by immunofluorescent antibody technique, the staining was observed exclusively in the nuclei 


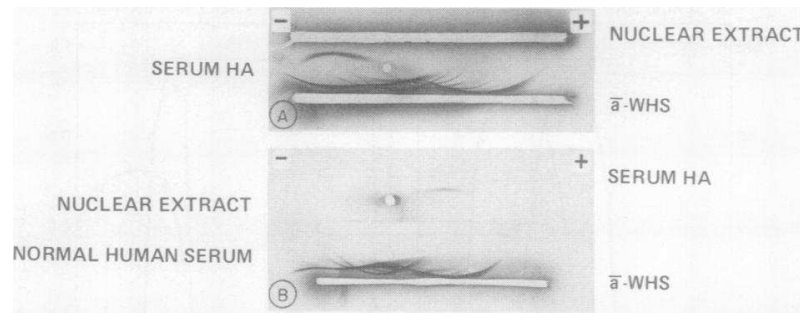

FIGURE 7 Electrophoretic mobility of the $\mathrm{Ha}$ antigen and anti-Ha. The serum HA was electrophoresed and reacted against calf thymus nuclear extract in the upper trough (nuclear extract) and anti-whole human serum (ā-WHS, lower trough) (Fig. 7A). The calf thymus nuclear extract and normal human serum were electrophoresed simultaneously. The rapid anodal mobility of the $\mathrm{Ha}$ antigen is illustrated (Fig 7B).

and had a "speckled" pattern (Fig. 8). Identical speckled nuclear fluorescence patterns were given by the original serum HA (Fig. 8A) and the purified antibody (Fig. 8B). Antibodies purified with nuclear extract of calf or rat liver showed the same results.

Distinguishing antibody to $\mathrm{Ha}$ antigen from the rheumatoid factor. Four sera with both precipitating antibodies to the $\mathrm{Ha}$ antigen and the positive latex fixation test for rheumatoid factor (titers, 1:640 to 1 : 5120) were absorbed with latex particles coated with human IgG. After absorption all the sera became negative for rheumatoid factor at 1:20 dilution but the precipitin reactions to the $\mathrm{Ha}$ antigen were not
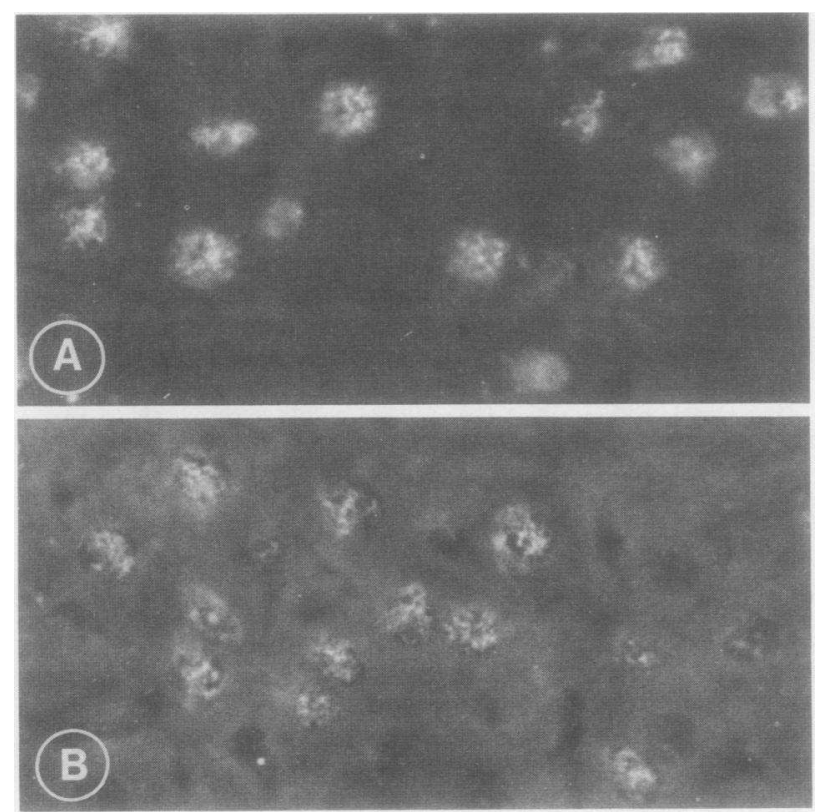

FIGURE 8 The speckled nuclear fluorescence pattern yielded by the original serum HA (1:20 dilution) (Fig 8A) and the purified antibody (Fig 8B).
TABLE II

Incidence of Precipitating Antibodies to the HA Antigen in Various Rheumatic Diseases

\begin{tabular}{lccc}
\hline \multicolumn{1}{c}{ Diagnoses* } & $\begin{array}{c}\text { Number } \\
\text { of } \\
\text { patients }\end{array}$ & $\begin{array}{l}\text { Number } \\
\text { positive }\end{array}$ & $\begin{array}{r}\text { Percent } \\
\text { positive }\end{array}$ \\
\hline SLE & 137 & 18 & 13 \\
Sjögren's syndrome & 15 & 5 & 30 \\
Scleroderma & 47 & 0 & 0 \\
Polymyositis & 11 & 0 & 0 \\
RA & 45 & 0 & 0 \\
MCTD & 16 & 0 & 0 \\
Healthy subjects & 20 & 0 & 0 \\
\hline
\end{tabular}

* RA, rheumatoid arthritis.

changed. Treatment of sera with 2-mercaptoethanol also did not affect the antibody reactivity.

Frequency of antibodies to the Ha antigen. Table II shows the incidence of antibodies to the $\mathrm{Ha}$ antigen examined by immunodiffusion. For this purpose, the optimal dilution of the serum and the concentration of the nuclear extract were first determined for each test serum which was positive on the screening test. The specificity of precipitin lines was established with reference sera. 18 of 137 sera of SLE patients (13\%) and 5 of 15 sera obtained from patients with Sjögren's syndrome (30\%) contained precipitating antibodies to the $\mathrm{Ha}$ antigen. In the present study, none of the patients with scleroderma, polymoysitis, rheumatoid arthritis, MCTD, or healthy controls had the antibodies to $\mathrm{Ha}$.

\section{DISCUSSION}

This report describes an antigen in the nuclear extract, tentatively named the $\mathrm{Ha}$ antigen, which is distinct from the $\mathrm{Sm}$ and RNP antigens. The $\mathrm{Ha}$ antigen is also different from other nuclear antigens such as DNA, DNA-histone, histone, single or doublestranded RNA, and the soluble nuclear antigen described by Holman (14). Some of the features of the $\mathrm{Ha}$ antigen resemble those of the antigen described by Beck as the "speckled" nuclear antigen (13). Beck's saline soluble antigen was a heat labile protein with a sedimentation coefficient of approximately $2.0 \mathrm{~S}$; however, other characteristics of that system such as gel diffusion pattern were not reported. Another antigen described by Anderson et al. and Beck et al., $\mathrm{SjT}$, was susceptible to trypsin digestion and heating for $60 \mathrm{~min}$ at $55^{\circ} \mathrm{C}(39,40)$. But the intracellular location of $\mathrm{Sj}$ was not determined.

The Alspaugh and Tan " $B$ " antigen $(21,22)$, while prepared from whole cell lysates rather than nuclei and not characterized in detail, is similar to $\mathrm{Ha}$ in trypsin sensitivity and the speckled nuclear fluores- 
cence given by its antibody. It differs in heat stability and the apparent absence of antibody in SLE serums. Together with Alspaugh and Tan, we have compared the two systems by immunodiffusion and find them to form lines of identity. Presumably the antigens are identical or very similar.

The soluble nature of the $\mathrm{Ha}$ antigen was confirmed by the fact that it could be extracted with physiologic saline and recovered in the supernate of high speed centrifugation $(106,000 \mathrm{~g}, 120 \mathrm{~min})$. The results of immunoelectrophoresis suggest an acidic character. Susceptibility to proteolytic but not to nucleolytic enzymes, plus heat and $\mathrm{pH}$ sensitivities, suggest that $\mathrm{Ha}$ is a protein.

The intracellular location of the $\mathrm{Ha}$ antigen was established by specific antibody prepared from immune precipitates. The $\mathrm{Ha}$ antigen localized within the nuclei of the liver, kidney, or thyroid cells of the rat or mouse. The nuclear fluorescence pattern was "speckled," adding the Ha system to the Sm and RNP systems in causing a speckled fluorescent antinuclear antibody pattern $(17,41)$.

Results obtained by sucrose density centrifugation, immunoelectrophoresis, and 2-mercaptoethanol treatment of reactive sera indicate that antibodies to the $\mathrm{Ha}$ antigen belong to IgG class (within the limitation of sensitivities of the methods used). Nevertheless, the fact that the majority $(90 \%)$ of sera with precipitating antibodies to the $\mathrm{Ha}$ antigen were also positive for rheumatoid factor raised the possibility that rheumatoid factor was the reactant. Absorption studies excluded this possibility.

It appears that there are correlations between clinical characteristics and autoantibody patterns in immunological diseases. The antibody to DNA is related to the renal disease of SLE (42). The antibody to the RNP antigen, found in patients with SLE and scleroderma, is characteristically present in MCTD $(18-20,41)$. Antibody to the Sm antigen, when present in high titer, appears to be associated with a hypocomplementemic variant of SLE with low titers of antibody to DNA and mild renal disease. ${ }^{2}$ We have found antibodies to the $\mathrm{Ha}$ antigen only in patients with SLE and Sjögren's syndrome in this study. Preliminary evidence indicates that many of these SLE patients have the sicca syndrome. Thus, it is possible that another autoantibody correlates with a particular clinical expression of disease.

At this time, only the antibody to DNA can be implicated in pathogenesis of lesions. It is possible that the other autoantibodies are a consequence of lesions rather than a cause. Nonetheless, the emergence of the correlations aids in focusing study of particular subsets of SLE. Perhaps discriminating information about pathogenesis, prognosis, and treatment will result.

\section{ACKNOWLEDGMENT}

This work was supported in part by U. S. Public Health Service grants AM 05425 and AI 11313.

\section{REFERENCES}

1. Robbins, W. C., H. R. Holman, H. Deicher, and H. G. Kunkel. 1957. Complement fixation with cell nuclei and DNA in lupus erythematosus. Proc. Soc. Exp. Biol. Med. 96: 575-579.

2. Seligmann, M. 1957. Mise en évidence dans le sérum de malades atteints de Lupus erythémateux disséminé d'une substance déterminant une réaction de precipitation avec l'acide desoxyribonucleique. C. R. Acad. Sci. (Paris). 245: 243-245.

3. Ceppellini, R., E. Polli, and F. Celada. 1957. A DNAreacting factor in serum of a patient with lupus erythematosus diffusus. Proc. Soc. Exp. Biol. Med. 96: 572-574.

4. Pearson, C. M., C. G. Craddock, and N. S. Simmons. 1958. Complement fixation reactions with DNA and leukocyte material in systemic lupus erythematosus. Correlation with the L. E. cell phenomenon and the clinical status. J. Lab. Clin. Med. 52: 580-587.

5. Holman, H. R., and H. G. Kunkel. 1957. Affinity between the lupus erythematosus serum factor and cell nuclei and nucleoprotein. Science (Wash. D. C.). 126: 162-163.

6. Holman, H. R., H. R. G. Deicher, and H. G. Kunkel. 1959. The L. E. cell and the L. E. serum factors. Bull. N. Y. Acad. Med. 35: 509-418.

7. Stollar, B. D. 1969. Rabbit and human antibodies to histone fractions. Fed. Proc. 28: 696. (Abstr.)

8. Steinberg, A. D., S. Baron, and N. Talal. 1969. The pathogenesis of autoimmunity in New Zealand mice. I. Induction of antinucleic acid antibodies by polyinosinic-polycytidylic acid. Proc. Natl. Acad. Sci. U.S.A. 63: $1102-1107$.

9. Schur, P. H., and M. Monroe. 1969. Antibodies to ribonucleic acid in systemic lupus erythematosus. Proc. Natl. Acad. Sci. U.S.A. 63: 1108-1112.

10. Beck, J. S. 1961. Variations in the morphological patterns of "autoimmune" nuclear fluorescence. Lancet. 1: 12031205.

11. Pinnas, J. L., J. D. Northway, and E. M. Tan. 1973. Antinucleolar antibodies in human sera. J. Immunol. 111: $996-1004$.

12. Miyawaki, S., and R. F. Ritchie. 1973. Nucleolar antigen specific for antinucleolar antibody in the sera of patients with systemic rheumatic disease. Arthritis Rheum. 16: 726-736.

13. Beck, J. S. 1962. Partial identification of the "speckled" nuclear antigen. Lancet. 1: 241-242.

14. Holman, H. R. 1965. Partial purification and characterization of an extractable nuclear antigen which reacts with SLE sera. Ann. N.Y. Acad. Sci. 124: 800-806.

15. Tan, E. M., and H. G. Kunkel. 1966. Characteristics of a soluble nuclear antigen precipitating with sera of patients with systemic lupus erythematosus. J. Imunol. 96: 464-471.

16. Sharp, G. C., W. S. Irvin, R. L. LaRoque, C. Velez, V. Daly, A. D. Kaiser, and H. R. Holman. 1971. Association of autoantibodies to different nuclear antigens with clinical patterns of rheumatic disease and responsiveness to therapy. J. Clin. Invest. 50: 350-359.

17. Mattioli, M., and M. Reichlin. 1971. Characterization of a soluble nuclear ribonucleoprotein antigen reactive with SLE sera. J. Immunol. 107: 1281-1290. 
18. Sharp, G. C., W. S. Irvin, E. M. Tan, R. G. Gould, and H. R. Holman. 1972. Mixed connective tissue diseasean apparently distinct rheumatic disease syndrome associated with a specific antibody to an extractable nuclear antigen (ENA). Am. J. Med. 52: 148-159.

19. Reichlin, M., and M. Mattioli. 1972. Correlation of a precipitin reaction to an RNAprotein antigen and a low prevalence of nephritis in patients with systemic lupus erythematosus. N. Engl. J. Med. 286: 908-911.

20. Parker, M. D. 1973. Ribonucleoprotein antibodies: Frequency and clinical significance in systemic lupus erythematosus, scleroderma and mixed connective tissue disease. J. Lab. Clin. Med. 82: 769-775.

21. Alspaugh, M. A., and E. M. Tan. 1975. Antibodies to cellular antigens in Sjögren's Syndrome. J. Clin. Invest. 55: $1067-1073$.

22. Alspaugh, M. A., N. Talal, and E. M. Tan. 1976. Differentiation and characterization of autoantibodies and their antigens in Sjögren's Syndrome. Arthritis Rheum. 19: 216-222.

23. Fries, J. F., and R. C. Siegel. 1973. Testing the preliminary criteria for classification of SLE. Ann. Rheum. Dis. 32: 171-177.

24. Ropes, M. W., G. A. Bennett, S. Cobb, R. Jacox, and R. A. Jessar. 1958. 1958 Revision of diagnostic criteria for rheumatoid arthritis. Bull. Rheum. Dis. 9: 175-176.

25. Medsger, T. A., Jr., H. Robinson, and A. T. Masi. 1971. Factors affecting survivorship in polymyositis. A lifetable study of 124 patients. Arthritis Rheum. 14: 249258.

26. Holman, H., and H. R. Deicher. 1959. The reaction of the lupus erythematosus (L. E.) cell factor with deoxyribonucleoprotein of the cell nucleus. J. Clin. Invest. 38: 2059-2072.

27. Maggio, R., P. Siekevitz, and G. E. Palade. 1963. Studies on isolated nuclei. I. Isolation and chemical characterization of a nuclear fraction from guinea pig liver. $J$. Cell. Biol. 18: 267-291.

28. Campbell, D. H., J. S. Garvey, N. E. Cremer, and D. H. Sussdorf. 1970. Gel diffusion. In Methods in Immunology. W. A. Benjamin, Inc., Menlo Park, Calif. 2nd edition. 250.

29. Wasserman, E., and L. Levine. 1961. Quantitative microcomplement fixation and its use in the study of antigenic structure by specific antigen-antibody inhibition. J. Immunol. 87: 290-295.
30. Osler, A. G., J. H. Strauss, and M. M. Mayer. 1952. Diagnostic complement fixation. I. A method. Amer. J. Syph. 36: $140-153$.

31. Stavitzky, A. B. 1954. Micromethods for the study of proteins and antibodies. I. Procedure and general applications of hemagglutination and hemagglutination-inhibition reactions with tannic acid and protein-treated red blood cells. J. Immunol. 72: 360-367.

32. Rothfield, N. F., B. Fragione, and E. C. Franklin. 1965. Slowly sedimenting mercaptoethanol-resistant antinuclear factors related antigenically to $M$ immunoglobulins ( $\gamma$ lm-globulin) in patients with systemic lupus erythematosus. J. Clin. Invest. 44: 62-72.

33. Clark, G., M. Reichlin, and T. B. Tomasi, Jr. 1969. Characterization of a soluble cytoplasmic antigen reactive with sera from patients with systemic lupus erythematosus. J. Immunol. 102: 117-122.

34. Kunkel, H. G. 1960. Macroglobulins and high molecular weight antibodies. In The Plasma Proteins. F. W. Putnam, editor. Academic Press, Inc., New York. 1: Chapter 8.

35. Scheidegger, J. J. 1955. Une micro-methode de l'immunoelectrophorese Int. Arch. Allergy Appl. Immunol. 7: 103-110.

36. Lowry, O. H., N. H. Rosebrough, A. L. Farr, and R. J. Randall. 1951. Protein measurement with the Folin phenol reagent. J. Biol. Chem. 193: 265-275.

37. Ceriotte, G. 1955. Determination of nucleic acids in animal tissues. J. Biol. Chem. 214: 59-70.

38. Giles, K. W., and A. Myers. 1965. An improved diphenylamine method for the estimation of deoxyribonucleic acid. Nature (Lond.). 206: 93.

39. Anderson, J. R., K. G. Gray, J. S. Beck, W. W. Buchanan, and A. J. McElhinney. 1962. Precipitating auto-antibodies in connective tissue diseases. Ann. Rheum. Dis. 21: 360-369.

40. Beck, J. S., J. R. Anderson, K. G. Gray, and N. R. Rowell. 1963. Antinuclear and precipitating autoantibodies in progressive systemic sclerosis. Lancet. 2: 1188-1190.

41. Northway, J. D., and E. M. Tan. 1972. Differentiation of antinuclear antibodies giving speckled staining patterns in immunofluorescence. Clin. Immunol. Immunopathol. 1: 140-154.

42. Koffler, D., P. H. Schur, and H. G. Kunkel. 1967. Immunological studies concerning the nephritis of systemic lupus erythematosus. J. Exp. Med. 126: 607-623. (and plates 47-50). 